\title{
Potential of renewable energy biogas from plant (Hyacinth)
}

\author{
Riswanto $^{1}$, Sodikin ${ }^{2}$ \\ 1, Physics Education Program, Muhammadiyah University Of Metro, Lampung \\ Jl. Ki Hajar Dewantara No.116 Iringmulyo Kota Metro, 34111, Lampung
}

2, , Physics Education Program, Islamic State Islamic Univesity Radin Intan of Lampung Jl. Letnan Kolonel H. Endro Suratmin, Sukarame, Kota Bandar Lampung, 35131, Lampung

Email : rumbiariswan@gmail.com

Received 23 August 2018, Revised 2 September 2018, Published 30 September 2018

\begin{abstract}
Energy is one of the basic human needs, both in the form of electricity and energy in the form of heat / gas. The increase in Indonesia's population has increased by $1.3 \%$ every year, this is comparable to the increase in energy needs. Current conditions illustrate that the fulfillment of energy needs is sourced more from fossil materials that cannot be renewed, therefore a solution is needed to overcome these problems by finding and finding potential alternative energy sources that can meet human needs. One of the energy that can be utilized is biogas. Biogas is a process of fermentation of organic matter that produces methane gas. Organic materials available in nature are abundant, one of which is organic matter derived from water hyacinth. For this reason, a research study is needed by identifying the potential of biogas energy from water hyacinth. This research is an experimental research, the data collection technique is done by quantitative methods. The tools needed are a manometer, thermometer and biogas reactor. This research was conducted by measuring the temperature and pressure produced by biogas made from organic water hyacinth. The results obtained showed that the biogas produced from water hyacinth produced a gas odor that was relatively not too stinging and the gas formation process was faster. Gas pressure measurements are carried out using a monometer by calculating the difference in the height of water pressure in the $U$ pipe. Measurements of pressure changes are carried out for 20 days by conditioning external factors such as temperature and humidity. The study was conducted to examine the effect of adding water hyacinth to biogas organic matter. The results obtained that $t$ count $>t$ table is the value of $t$ arithmetic (8.183) $>\mathrm{t}$ table $(2.093)$ and the significance level of $0.000<0.05$. This means that there are differences in biogas production between before adding water hyacinth and after adding water hyacinth.
\end{abstract}

Keywords: Renewable Energy, Biogas

\section{Introduction}

Law of the Republic of Indonesia Number 30 of 2007 states that in the framework of supporting national development in a sustainable manner and increasing national energy security, several energy management objectives have been established including: a). 
achieving energy management independence; b). Guaranteed availability of domestic energy, both from domestic and foreign sources; d. guaranteed management of energy resources in an optimal, integrated and sustainable manner; e. energy use is efficient in all sectors; f. the achievement of increased access of the poor and / or those living in remote areas to energy to realize the welfare and prosperity of the people fairly and evenly The priority of energy development as stated in Government Regulation Number 79 of 2014 concerning National Energy Policy in Paragraph 2 Article 11 point c stated that the development of Energy prioritizes Energy resources in the local environment. Based on the description of the above policy, it can be stated that alternative energy development must be optimized, especially the potential of alternative energy sources that are cheap and easily obtained in the surrounding environment.

Increased energy needs must be addressed wisely and intelligently by processing alternative energy sources. Many potential biogas energy sources can be developed both from various animal manure and from certain plants. The following describes the composition of mixed cow manure with various materials referring to the results of research from various sources as follows:

1. Based on the results of research by Guyup Mahardian Dwi Putra, et al. (2017), it is suggested that the ideal composition of comparisons in biogas formation uses cow dung and water, with a ratio of 1: 2 .

2. The results of the Renilaili study (2015) explain that the use of water hyacinth as environmentally friendly energy in the form of biogas will produce maximal gas (COD) production in the ratio of water hyacinth composition to cow dung is $75 \%: 25 \%$.

3. The research results of Dewi Ayu Trisno Wati and Sugito (2013) showed that through 3 variations and 3 repetitions obtained the composition of tofu waste mixture with cow dung which produced the highest gas pressure occurred in the composition of $50 \%$ cow manure and $50 \%$ tofu industry wastewater.

4. Research by Adam Fairuz, et al. (2015) states that based on the results of the C / $\mathrm{N}$ ratio and flame test, the optimal composition is obtained by the treatment of 50: 50: 0 composition with the composition of banana peel, cow dung, and coconut pulp.

5. The results of the research of R. Haryo Bimo Setiarto (2016) revealed that the method of making biogas from straw is by chopping straw into sizes $4-5 \mathrm{~cm}$ and then put into a sink and added water. The comparison between water and rice straw is $1: 3$.

The results of field survey about potential energy biogas plant in the Metro City obtained the following results 


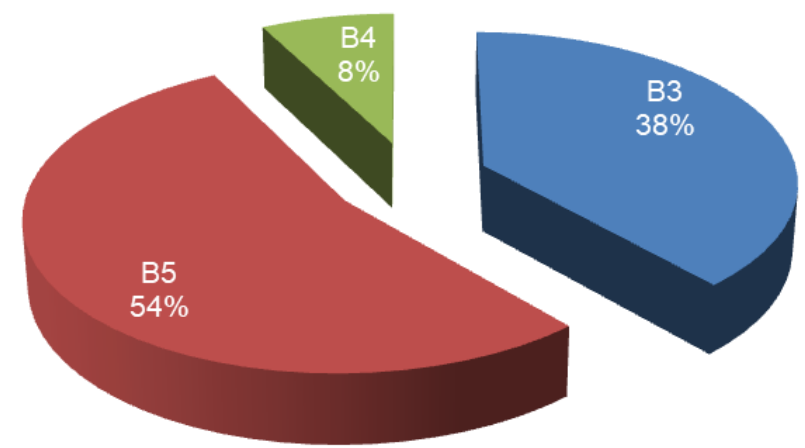

Figure 1. Results of the survey on the potential of Biogas Plants

According to Nielsen (2009) The EU policies concerning renewable energy systems (RES) have set forward a fixed goal of supplying $20 \%$ of the European energy demands from RES by year 2020. And at least $25 \%$ of all bioenergy in the future can originate from biogas, produced from wet organic materials such as: animal manure, whole crop silages, wet food and feed wastes, etc. Based on the above figure 1, research results Riswanto and Muhammad Barkah Salim (2017) suggests that the type of material of biogas plants, which have the highest percentage of IE code B5 from rice straw with a value amounting to 54\%, while for B3 (waste) as much as 38\% and B4 (banana peels) by $8 \%$, other potential may still be developed, namely the existence of water hyacinth at the border of Central lampung Regency and city. Research Weiss (2008) Biogas plants continuously convert biological wastes mainly into a mixture of methane, $\mathrm{CO}_{2}$ and $\mathrm{H}_{2} \mathrm{O}$ - a conversion that is carried out by a consortium of bacteria and archaea. Especially in the municipal plants dedicated towards waste treatment, the reactor feed may vary considerably, exposing the resident microbiota to a changing variety of substrates.

The existence of water hyacinth which is considered as a weed has the potential to be utilized as an ingredient in a mixture of biogas as disclosed in the study renilaili (2015). But the level of influence that was given is not yet measurable, that needs to be done to identify potential sources of renewable energy from biogas derived from water hyacinth. The potential influence of additions include examined mix hyacinth toward the production of biogas is produced, it also needs to be done in physical review with the indication of the color and the smell of the gas resulting from the mixing of the water hyacinth. Design for reaktor biogas plant, according Sammer (2012) In order to plan a biogas plant and to design a digester, several design parameters must be determined which are: ratio of gathered waste from manure canals to total waste, number ofcows in farm, amount of manure produced by a cow which is usually $1.8 \mathrm{~m} 3 \mathrm{cow}-1$ month1,quantity of daily liquid organic matter deposition into the digester, hydraulic retention time, density and quantity of daily dry organic matter deposition into the digester, and digester load which is usually $2-4 \mathrm{~kg} \mathrm{~m}-3$ day- 1 . 


\section{Research Method}

This research is a research experiment with the aim to identify potential sources of biogas energy from water hyacinth. The research method used can be described through the following pictures 2 .

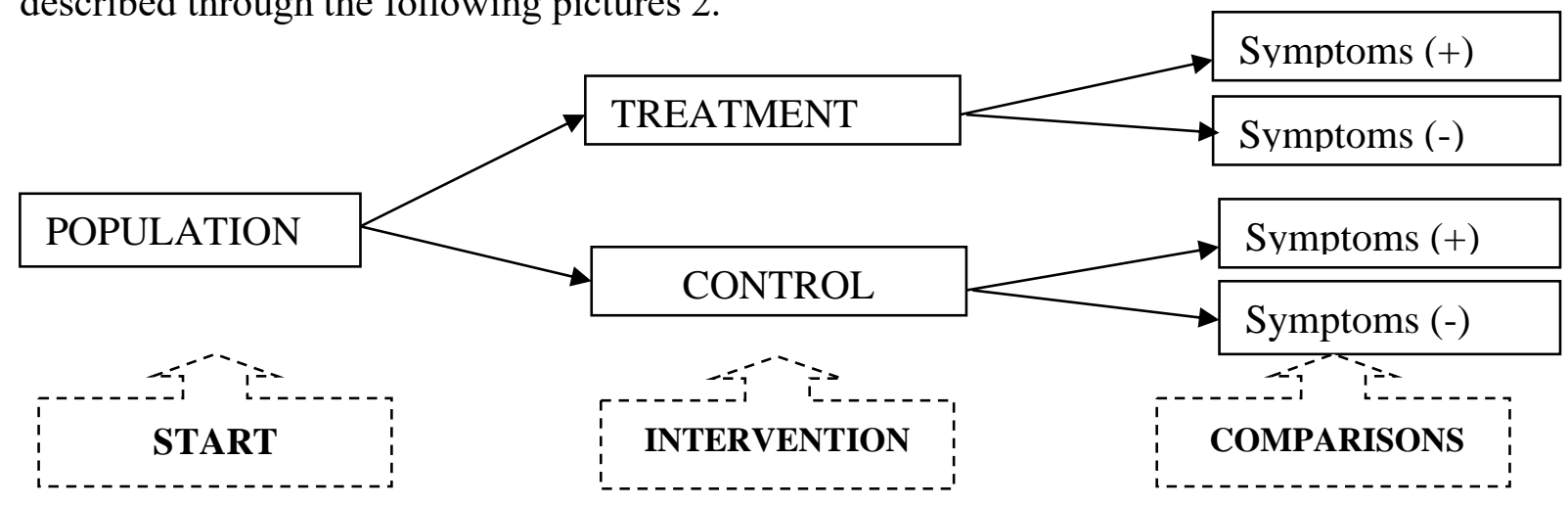

Figure 2. Research Methods

Based on Figure 2 can be expressed that this research was conducted in two data retrieval. Data-1 is referred to as control data i.e. biogas production measurements performed using organic materials in the form of cow dung, then conducted the recording of a change of pressure for 20 days. Data- 2 is referred to as the data treatment i.e. biogas production measurement is done using a mixture of cow dung added with water hyacinth, time recording done during 20 days. Rohyami (2012) revealed a calculation pressure biogas produced can be calculated using Boyle's law as the equation below.

$$
\mathrm{P}=\rho . g \cdot h+\text { tekanan atmosfer }
$$

Information :

$\mathrm{P}=$ absolute pressure $(\mathrm{N} / \mathrm{m} 2)$

$\rho=$ density of the liquid $(\mathrm{kg} / \mathrm{m} 3)=1000 \mathrm{~kg} / \mathrm{m} 3$

$\mathrm{g}=$ acceleration of gravity $(9.81 \mathrm{~m} / \mathrm{s} 2)$

$\mathrm{h}=$ difference in height of the column of liquid substance used (m)

$1 \mathrm{~atm}=101,325 \mathrm{~N} / \mathrm{m} 21 \mathrm{~N} / \mathrm{m} 2=9,869 \times 10-6 \mathrm{~atm}$

Technique of data analysis in this study is carried out quantitative and qualitative like the following description: 
Table 1. Analysis Techniques Data collection

\begin{tabular}{|c|c|c|c|c|}
\hline No & The purpose of & Aspects of the & Method/Instrument & $\begin{array}{l}\text { Analysis } \\
\text { techniques }\end{array}$ \\
\hline 1 & $\begin{array}{l}\text { Knowing the } \\
\text { influence of } \\
\text { addition of water } \\
\text { hyacinth as a } \\
\text { mixture of biogas }\end{array}$ & $\begin{array}{l}\text { Data abosolut } \\
\text { pressure } \\
\text { measurement } \\
\text { results of biogas }\end{array}$ & $\begin{array}{ll} & \text { Paired T test } \\
\text { - } & \text { Tabulated data } \\
& \text { capture sheet }\end{array}$ & $\begin{array}{c}\text { Quantitative } \\
\text { analysis }\end{array}$ \\
\hline 2 & $\begin{array}{l}\text { Identify the } \\
\text { differences in the } \\
\text { physical mixture } \\
\text { of water hyacinth } \\
\text { biogas }\end{array}$ & $\begin{array}{l}\text { Physical } \\
\text { description } \\
\text { biogas }\end{array}$ & $\begin{array}{l}\text { The observation } \\
\text { sheet and physical } \\
\text { description of the } \\
\text { smell and color }\end{array}$ & $\begin{array}{l}\text { Qualitative } \\
\text { analysis }\end{array}$ \\
\hline 3 & $\begin{array}{l}\text { Knowing the } \\
\text { user response } \\
\text { tool }\end{array}$ & $\begin{array}{l}\text { Eligibility as a } \\
\text { medium and user } \\
\text { response }\end{array}$ & $\begin{array}{l}\text { user response data } \\
\text { Tabulated the results } \\
\text { of question }\end{array}$ & $\begin{array}{c}\text { Qualitative } \\
\text { Analysis }\end{array}$ \\
\hline
\end{tabular}

Statistical tests used using the paired T Test, with the research hypothesis is as follows:

$\mathrm{H}_{0}$ : there is no difference between the produced gas pressure before the added water hyacinth with after the added water hyacinth.

$\mathrm{H}_{\mathrm{a}}$ : there is a difference between the produced gas pressure before the added water hyacinth with after the added water hyacinth.

\section{Data Processing and Analysis}

The study was done by comparing the results of measurements of biogas using cow dung with measurement results the biogas using a mixture of cow dung and water hyacinth. The following data the results of the measurements made during 20 days.

Table 2. Data measurement pressure biogas for cow dung

\begin{tabular}{lllccccc}
\hline $\mathrm{No}$ & $\mathrm{h}_{\mathrm{i}}$ & $\mathrm{h}_{2}$ & $\Delta \mathrm{h}(\mathrm{cm})$ & $\Delta \mathrm{h}(\mathrm{m})$ & $\mathrm{P}\left(\mathrm{N} / \mathrm{m}^{2}\right)$ & $\mathrm{P}+\mathrm{P}$ atm $\left(\mathrm{N} / \mathrm{m}^{2}\right)$ & $\mathrm{P}+\mathrm{P}$ atm $(\mathrm{atm})$ \\
\hline 1 & 52,5 & 52,5 & 0 & 0 & 0 & 101,325 & 403419,2827 \\
2 & 52,5 & 52,6 & 0,1 & 0,001 & 9,81 & 111,135 & 442477,1969 \\
3 & 52,5 & 52,9 & 0,4 & 0,004 & 39,24 & 140,565 & 559650,9397 \\
4 & 52 & 53 & 1 & 0,01 & 98,1 & 199,425 & 793998,4253 \\
5 & 52,2 & 54,8 & 2,6 & 0,026 & 255,06 & 356,385 & 1418925,054 \\
6 & 52,8 & 54,2 & 1,4 & 0,014 & 137,34 & 238,665 & 950230,0824 \\
7 & 52,6 & 54,3 & 1,7 & 0,017 & 166,77 & 268,095 & 1067403,825 \\
8 & 52,3 & 54,6 & 2,3 & 0,023 & 225,63 & 326,955 & 1301751,311 \\
9 & 52,3 & 54,6 & 2,3 & 0,023 & 225,63 & 326,955 & 1301751,311 \\
10 & 52,2 & 54,3 & 2,1 & 0,021 & 206,01 & 307,335 & 1223635,482 \\
11 & 52,1 & 54,3 & 2,2 & 0,022 & 215,82 & 317,145 & 1262693,396 \\
12 & 52,2 & 54,3 & 2,1 & 0,021 & 206,01 & 307,335 & 1223635,482
\end{tabular}




\begin{tabular}{cccccccc}
\hline No & $\mathrm{h}_{\mathrm{i}}$ & \multicolumn{1}{c}{$\mathrm{h}_{2}$} & $\Delta \mathrm{h}(\mathrm{cm})$ & $\Delta \mathrm{h}(\mathrm{m})$ & $\mathrm{P}\left(\mathrm{N} / \mathrm{m}^{2}\right)$ & $\mathrm{P}+\mathrm{P}$ atm $\left(\mathrm{N} / \mathrm{m}^{2}\right)$ & $\mathrm{P}+\mathrm{P}$ atm $(\mathrm{atm})$ \\
\hline 13 & 52,1 & 54,4 & 2,3 & 0,023 & 225,63 & 326,955 & 1301751,311 \\
14 & 52,2 & 54,3 & 2,1 & 0,021 & 206,01 & 307,335 & 1223635,482 \\
15 & 52,2 & 54,6 & 2,4 & 0,024 & 235,44 & 336,765 & 1340809,225 \\
16 & 52,2 & 54,3 & 2,1 & 0,021 & 206,01 & 307,335 & 1223635,482 \\
17 & 52,5 & 54,1 & 1,6 & 0,016 & 156,96 & 258,285 & 1028345,911 \\
18 & 51,8 & 55 & 3,2 & 0,032 & 313,92 & 415,245 & 1653272,539 \\
19 & 52,4 & 55,1 & 2,7 & 0,027 & 264,87 & 366,195 & 1457982,968 \\
20 & 52,7 & 54,1 & 1,4 & 0,014 & 137,34 & 238,665 & 950230,0824 \\
\hline
\end{tabular}

Based on the data in table 2 can be expressed that the results of the measurement of biogas with cow dung showed increased pressure on day 6 and the highest pressure observed on day 18. The magnitude of the pressure measured by calculating the difference in altitude on the manometer.

Table 3. Data retrieval results for a mixture of cow dung and water hyacinth

\begin{tabular}{lllccccc}
\hline $\mathrm{No}$ & $\mathrm{h}_{\mathrm{i}}$ & $\mathrm{h}_{2}$ & $\Delta \mathrm{h}(\mathrm{cm})$ & $\Delta \mathrm{h}(\mathrm{m})$ & $\mathrm{P}\left(\mathrm{N} / \mathrm{m}^{2}\right)$ & $\mathrm{P}+\mathrm{P}$ atm $\left(\mathrm{N} / \mathrm{m}^{2}\right)$ & $\mathrm{P}+\mathrm{P}$ atm $(\mathrm{atm})$ \\
\hline 1 & 54,5 & 55,3 & 0,8 & 0,008 & 78,48 & 179,805 & 715882,5968 \\
\hline 2 & 54 & 56,6 & 2,6 & 0,026 & 255,06 & 356,385 & 1418925,054 \\
\hline 3 & 53,6 & 57,2 & 3,6 & 0,036 & 353,16 & 454,485 & 1809504,196 \\
\hline 4 & 52,3 & 58 & 5,7 & 0,057 & 559,17 & 660,495 & 2629720,396 \\
\hline 5 & 51,8 & 58,8 & 7 & 0,07 & 686,7 & 788,025 & 3137473,281 \\
\hline 6 & 49,4 & 61 & 11,6 & 0,116 & 1137,96 & 1239,285 & 4934137,337 \\
\hline 7 & 50 & 60,6 & 10,6 & 0,106 & 1039,86 & 1141,185 & 4543558,195 \\
\hline 8 & 48,2 & 62 & 13,8 & 0,138 & 1353,78 & 1455,105 & 5793411,451 \\
\hline 9 & 47,6 & 62,6 & 15 & 0,15 & 1471,5 & 1572,825 & 6262106,422 \\
\hline 10 & 46,2 & 63,9 & 17,7 & 0,177 & 1736,37 & 1837,695 & 7316670,108 \\
\hline 11 & 46,7 & 63,3 & 16,6 & 0,166 & 1628,46 & 1729,785 & 6887033,051 \\
\hline 12 & 46,3 & 63,7 & 17,4 & 0,174 & 1706,94 & 1808,265 & 7199496,365 \\
\hline 13 & 43,6 & 66,5 & 22,9 & 0,229 & 2246,49 & 2347,815 & 9347681,649 \\
\hline 14 & 43 & 66 & 23 & 0,23 & 2256,3 & 2357,625 & 9386739,564 \\
\hline 15 & 43,3 & 66,4 & 23,1 & 0,231 & 2266,11 & 2367,435 & 9425797,478 \\
\hline 16 & 43,1 & 66,2 & 23,1 & 0,231 & 2266,11 & 2367,435 & 9425797,478 \\
\hline 17 & 42,5 & 67 & 24,5 & 0,245 & 2403,45 & 2504,775 & 9972608,278 \\
\hline 18 & 43 & 66,3 & 23,3 & 0,233 & 2285,73 & 2387,055 & 9503913,306 \\
\hline 19 & 43,1 & 66,2 & 23,1 & 0,231 & 2266,11 & 2367,435 & 9425797,478 \\
\hline 20 & 43,1 & 66,2 & 23,1 & 0,231 & 2266,11 & 2367,435 & 9425797,478 \\
\hline
\end{tabular}

Based on table 3, the result of a mixture of cow dung and plant water hyacinth showed results on day 2 showed the highest pressure and pressure changes occur on day 17. Comparison of results data in tables 2 and 3 seem on the pressure measurement results. On cow manure generated pressure smaller mixed materials in cow dung with water hyacinth biogas generated pressure is greater. Presented the following properties of the second data table data: 


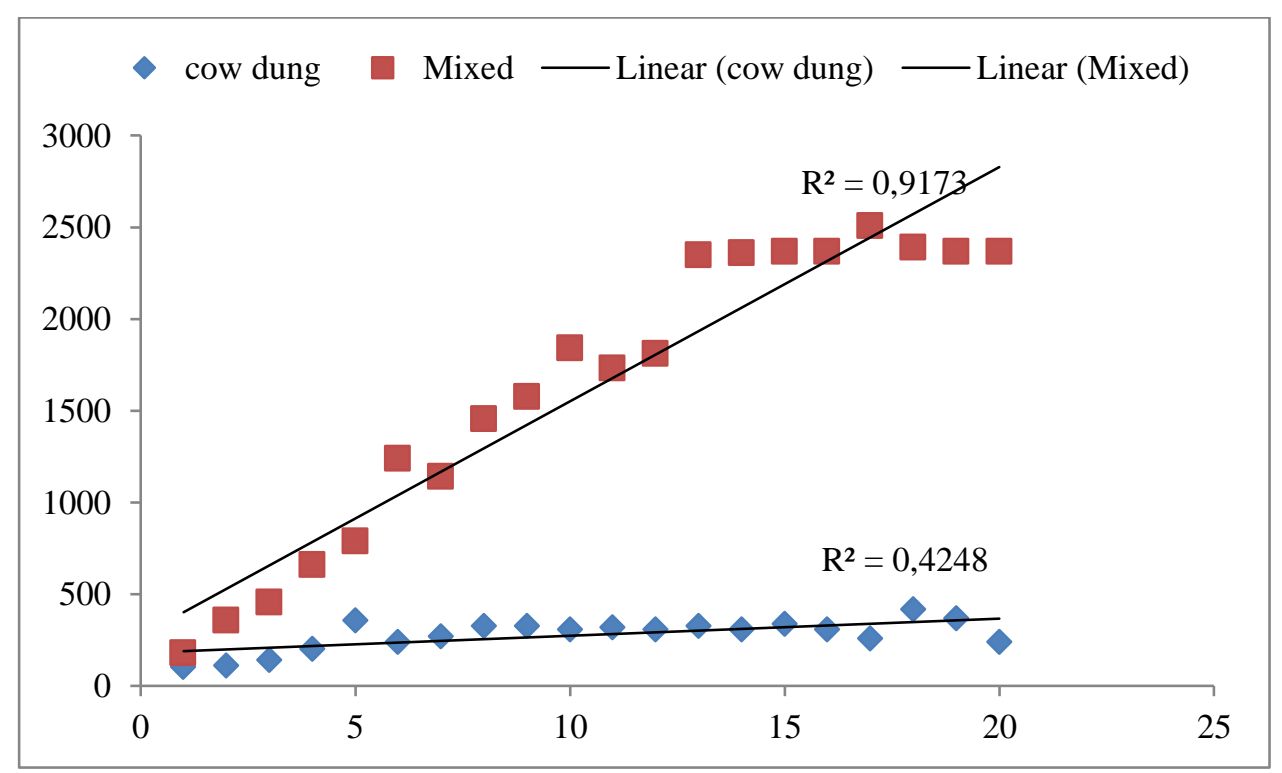

Figure 2. Changes in the pressure of biogas fermentation with respect to time

Presented the following Paired $\mathrm{T}$ test results data_1 as data controls and data provided as data_2 treatment

Table 2. The paired T test results using SPSS

Paired Samples Test

\begin{tabular}{|c|c|c|c|c|c|c|c|c|}
\hline & \multicolumn{5}{|c|}{ Paired Differences } & \multirow[b]{3}{*}{$t$} & \multirow[b]{3}{*}{$\mathrm{df}$} & \multirow[b]{3}{*}{ Siq. (2-tailed) } \\
\hline & \multirow[b]{2}{*}{ Mean } & \multirow[b]{2}{*}{ Std. Deviation } & \multirow{2}{*}{$\begin{array}{l}\text { Std. Error } \\
\text { Mean }\end{array}$} & \multicolumn{2}{|c|}{$\begin{array}{l}95 \% \text { Confidence Interval of the } \\
\text { Difference }\end{array}$} & & & \\
\hline & & & & Lower & Upper & & & \\
\hline Pair 1 Data_1 - Data_2 & $\begin{array}{r}-1,336,6 \\
12.500\end{array}$ & $730,481.063$ & $163,340.531$ & $-1,678,488.16$ & $-994,736.839$ & -8.183 & 19 & .000 \\
\hline
\end{tabular}

Results of statistical tests on the data using SPSS obtained that $t$ count is - nilat 8.183 , to t the table by using the Ms Excel program $\operatorname{TINV}(0.05 ; 19)$ is 2.093 . Then based on decision making as follows:

a. $\mathrm{t}$ count $\leq \mathrm{t}$ table atau $-\mathrm{t}$ count $\geq$ the table then $\mathrm{H}_{0}$ is accepted

b. $t$ count $>t$ table or $-\mathrm{t}$ count $<$ the table then $\mathrm{H}_{0}$ is rejected

Based on table 2 it can be known that $\mathrm{t}$ count $>\mathrm{t}$ table that is the value $\mathrm{t}$ count is $8.183 \mathrm{t}$ table that is the value $\mathrm{t}$ count $8.183>\mathrm{t}$ tabel 2,093 While for $-\mathrm{t}$ count $<-$ table then the values of $\mathrm{H}_{0}$ tcount $-8,183<\mathrm{t}$ table $-2,093$. This means that there is a difference between biogas production prior to addition of water hyacinth with after the addition of the water hyacinth. This is by reviewing the results of the test of significance value $0.000<0.05$ with a conclusion that there is a difference of biogas production with the addition of water hyacinth. The following description of the observations of the formation process of the biogas is shown in Table 3. 
Table 3. Data research results

\begin{tabular}{|c|c|c|c|}
\hline No & $\begin{array}{l}\text { Type Of } \\
\text { Material }\end{array}$ & The composition of the & Physical properties \\
\hline 1 & Cow Dung & $\begin{array}{l}\text { A comparison of cow manure } \\
\text { and water that is } 1: 2\end{array}$ & $\begin{array}{l}\text { 1. Gas smell more pungent } \\
\text { 2. The process of formation of the gas } \\
\text { longer }\end{array}$ \\
\hline 2 & $\begin{array}{l}\text { A mixture of } \\
\text { cow dung and } \\
\text { water hyacinth }\end{array}$ & $\begin{array}{l}\text { 1. Water hyacinth in water } \\
\text { of } 1: 3 \\
\text { 2. Cow dung with water of } \\
1: 2 \\
\text { 3. A mixture of cow dung } \\
+ \text { mixed with water } \\
\text { hyacinth + the water is } \\
75 \%: 25 \% \text {. }\end{array}$ & $\begin{array}{l}\text { 1. The smell of the gas produced is } \\
\text { relatively not too strong. } \\
\text { 2. The process of formation of the gas } \\
\text { more quickly }\end{array}$ \\
\hline
\end{tabular}

\section{Result and Discussion}

\subsection{Result}

Based on the results of the research that has been done then it can be expressed as the following conclusions:

1. There is the influence of biogas production with the addition of the water hyacinth on cow dung, paired T-test results showed that $\mathrm{t}$ calculate $>\mathrm{t}$ table that is the value $\mathrm{t}$ calculate $(8.183)>\mathrm{t}$ table $(2.093)$ and the significance level $0.05<0.000$. This means that there is a difference between biogas production prior to addition of water hyacinth with after the addition of a water hyacinth.

2. The results of the analysis by reviewing the physical description of the character of the scent and the length of fermentation gas, can be addressed through the addition of water hyacinth that retrieved the smell of gas generated is relatively not too pungent, and the process of formation of the gas more quickly.

\subsection{Discussion}

Advice that can be given to the refinement of advanced study on biogas is as follows:

1. Need the developed gauges quantities biogas-based digital to ease in learning the characteristics of biogas data

2. The large number of potential organic materials that can be developed into biogas still need review and mapped based on the level of worthiness in terms of productivity or gas in terms of its versatility.

3. Need to be developed biogas reactors models that are more practical

\section{References}

Fairuz, A. (2015). Pengaruh penambahan ampas kelapa dan kulit pisang terhadap produksi biogas dari kotoran sapi (Doctoral dissertation, Fakultas Pertanian). 
Laili, R. (2015). Enceng Gondok Sebagai Biogas Yang Ramah Lingkungan. Jurnal Ilmiah Tekno, 12(1), 01-10

Holm-Nielsen, J. B., Al Seadi, T., \& Oleskowicz-Popiel, P. (2009). The future of anaerobic digestion and biogas utilization. Bioresource technology, 100(22), 5478-5484.

Putra, Guyup Mahardian Dwi, Rancang Bangun Reaktor Biogas Tipe Portable dari Limbah Kotoran Ternak Sapi. Jurnal Ilmiah Rekayasa Pertanian dan Biosistem. Vol 5 (1), pp. 369-374. 2017.

Riswanto, R. (2017). Pemetaan Potensi Biogas di Kota Metro. Jurnal Pendidikan Fisika, 5(2), 126-137.

Peraturan Pemerintah No. 3 tahun 2005 tentang Penyediaan dan pemanfaatan Tenaga Listrik

Peraturan Pemerintah Nomor 79 Tahun 2014 tentang Kebijakan Energi Nasional.

Rohyami. 2012. (online) .Hukum Gas ideal, http://rohyami.staff.uii.ac.id/2012/05/07/gas/ retrieved 17 July 2018.

Samer, M. (2012). Biogas plant constructions. In Biogas. IntechOpen.

Setiarto, R. H. B. (2016). Prospek Dan Potensi Pemanfaatan Lignoselulosa Jerami Padi Menjadi Kompos, Silase dan Biogas Melalui Fermentasi Mikroba. Jurnal Selulosa, 3(02).

Wati, D. A. T., \& Sugito, S. (2013). Pembuatan Biogas dari Limbah Cair Pabrik Tahu Dengan Tinja Sapi. WAKTU, 11(2), 55-61.

Weiss, A., Jérôme, V., Freitag, R., \& Mayer, H. K. (2008). Diversity of the resident microbiota in a thermophilic municipal biogas plant. Applied microbiology and biotechnology, 81(1), 163. 